\title{
Analisis Penerimaan Pajak Bumi Dan Bangunan Perdesaan Dan Perkotaan (PBB-P2) Terhadap Kontribusi Pendapatan Asli Daerah (PAD) Di Kota Gorontalo
}

\author{
ZULKIFLI $^{1}$, LINTJE KALANGI ${ }^{2}$, HENDRIK MANOSSOH ${ }^{3}$
}

\author{
1,2,3 Program Magister Akuntansi, Fakultas Ekonomi dan Bisnis Universitas Sam Ratulangi \\ email: zulkifli.sasaja@gmail.com ${ }^{1}$, lintjekalangi@yahoo.com ${ }^{2,}$ hendrikmanossoh@yahoo.com ${ }^{3}$
}

\begin{abstract}
Land and Building Tax of Rural and Urban Areas (PBB-P2) is one of the central taxes submitted to the local government to become a local tax. PBB-P2 as a regional tax is expected to contribute maximally to the regional revenue especially to the Local Own-Source Revenue (PAD). The objective of the study is to analyze the acceptance of PBB-P2 on the contribution of PAD and to analyze inhibiting factors and support for PBB-P2 revenues in Gorontalo City. This is a qualitative research and case study approach was deployed within this study. Gorontalo City Government is the research object. Data were collected by in-depth interviews and document study. Data was analysed by using codification, presentation of data and conclusions. Validity test was employed by credibility (internal validity), transferability (external validity) and dependability (reliability) tests. The results showed that the revenues of PBB-P2 in Gorontalo city based on the collection ratio were $69.47 \%$ in 2012, 74.44\% in 2013, 76.50\% in 2014, 81.26\% in 2015 and $86.75 \%$ in 2016. Classification of $P B B-P 2$ revenues in Gorontalo City based on analysis of the ratio of proportion and growth ratio is potential. The inhibiting factors of PBB-P2 revenue on the contribution of PAD revenue in Gorontalo City are taxpayers' awareness, data suitability, mistakes in designation documents, and human resources. On the other hand, factors that support the PBB-P2 revenue in Gorontalo City are leadership, human resources and compensation.
\end{abstract}

Keywords: Local Own-Source Revenue, PBB-P2 Receipts, Inhibiting Factors and Supporters.

\begin{abstract}
Abstrak. Pajak Bumi dan Bangunan Perdesaan dan Perkotaan (PBB-P2) adalah salah satu pajak pusat yang diserahkan pengelolaanya ke pemerintah daerah sehingga menjadi pajak daerah. PBB-P2 sebagai pajak daerah diharapkan dapat berkontribusi maksimal terhadap penerimaan daerah khususnya terhadap pendapatan asli daerah (PAD). Tujuan penelitian adalah untuk menganalisis penerimaan PBB-P2 terhadap kontribusi PAD dan menganalisis faktor-faktor penghambat dan pendukung penerimaan PBB-P2 di Kota Gorontalo. Metode penelitian menggunakan jenis kualitatif dengan pendekatan studi kasus dan Pemerintah Kota Gorontalo sebagai objek penelitian. Tehnik pengumpulan data dengan wawancara mendalam dan dokumentasi. Tehnik analisis data yang digunakan adalah kodifikasi, penyajian data dan kesimpulan. Uji keabsahan data dalam penelitian ini meliputi uji credibility (validitas internal), transferability (validitas eksternal) dan dependability (reliabilitas). Hasil penelitian menunjukkan bahwa penerimaan PBB-P2 di Kota Gorontalo berdasarkan rasio pengumpulan pada tahun 2012 sebesar 69,47\%, tahun 2013 sebesar 74,44\%, tahun 2014 sebesar 76,50\%, tahun 2015 sebesar $81,26 \%$ dan pada tahun 2016 rasio penerimaan PBB-P2 adalah sebesar 86,75\%. Klasifikasi penerimaan PBB-P2 di Kota Gorontalo berdasarkan analisis rasio proporsi dan rasio pertumbuhan adalah potensial. Faktor-faktor penghambat penerimaan PBB-P2 terhadap kontribusi penerimaan PAD di Kota Gorontalo adalah kesadaran wajib pajak, kesesuaian data, kekeliruan dalam dokumen penetapan, dan sumber daya manusia. Sementara faktor-faktor yang mendukung penerimaan PBB-P2 Di Kota Gorontalo adalah kepemimpinan, sumber daya manusia dan kompensasi.
\end{abstract}

Kata Kunci: Pendapatan asli daerah, Penerimaan PBB-P2, faktor-faktor penghambat dan pendukung.

\section{Pendahuluan}

Dalam rangka penyelenggaraan pemerintahan dan melaksanakan pembangunan, Negara Kesatuan Republik Indonesia dibagi atas daerah-daerah provinsi dan daerah provinsi tersebut terdiri atas daerah-daerah kabupaten dan kota. Setiap daerah mempunyai hak dan kewajiban untuk mengatur dan mengurus sendiri urusan pemerintahannya untuk meningkatkan penyelenggaraan pemerintahan dan pelayanan kepada masyarakat. Untuk melaksanakan pembangunan dan penyelenggaraan urusan pemerintahan di daerah, sumber dana memegang peranan penting dalam mewujudkan keberhasilan pembangunan dan pemerintahan. Salah satu sumber dana yang cukup berperan penting bagi kelangsungan pelaksanaan pembangunan dan penyelenggaran urusan pemerintahan adalah penerimaan dari pendapatan asli daerah yang salah satunya berasal dari pajak daerah.

Pada tanggal 15 September 2009, telah disahkan Undang-Undang Nomor 28 Tahun 2009 tentang Pajak Daerah dan Retribusi Daerah sebagai pengganti Undang-Undang Nomor 18 Tahun 1997 dan Undang-Undang Nomor 34 Tahun 2000 tentang Pajak Daerah dan Retribusi Daerah. Berlakunya 
Undang-Undang Nomor 28 Tahun 2009 tentang Pajak Daerah dan Retribusi Daerah (UU PDRD), maka pemerintah daerah memperoleh perluasan objek pajak daerah sebagai sumber penghasilan tambahan. Perluasan objek pajak daerah yang diatur dalam Undang-Undang tersebut meliputi perluasan basis pajak daerah yang telah ada, penambahan objek pajak baru dan pendaerahan objek pajak pusat menjadi pajak daerah salah yang satunya adalah Pajak Bumi dan Bangunan Perdesaan dan Perkotaan (PBB-P2).

Adapun dasar pemikiran dan alasan pokok dari pengalihan PBB-P2 menjadi pajak daerah, antara lain: Pertama, berdasarkan teori, PBB-P2 lebih bersifat lokal (local origin), visibilitas, objek pajak tidak berpindah-pindah (immobile), dan terdapat hubungan erat antara pembayar pajak dan yang menikmati hasil pajak tersebut (the benefit tax-link principle). Kedua, pengalihan PBB-P2 diharapkan dapat meningkatkan Pendapatan Asli Daerah (PAD) dan sekaligus memperbaiki struktur Anggaran Pendapatan dan Belanja Daerah (APBD). Ketiga, untuk meningkatkan pelayanan masyarakat (public services), akuntabilitas, dan transparansi dalam pengelolaan PBB-P2. Keempat, berdasarkan praktek di banyak negara, PBB -P2 atau Property Tax termasuk dalam jenis local tax (pedoman pengelolaan PBB-P2 : 2014).

Dengan ditetapkannya Peraturan Daerah Kota Gorontalo Nomor 9 Tahun 2011 tentang Pajak Bumi dan Bangunan Perdesaan dan Perkotaan, maka Pemerintah Kota Gorontalo telah mengelola PBB-P2 sejak tanggal 1 Januari 2012. Keadaan saat ini menunjukkan bahwa dengan dikelolanya PBBP2 oleh Pemerintah Kota Gorontalo telah mengalami peningkatan pada target dan realisasi penerimaan PBB-P2 sejak tahun 2012. Berikut gambar 1 yang menunjukkan grafik perbandingan antara target dan realisasi penerimaan PBB-P2 di Kota Gorontalo:

Gambar 1: Grafik Target dan Realisasi Penerimaan PBB-P2 Kota Gorontalo

Tahun 2012-2016

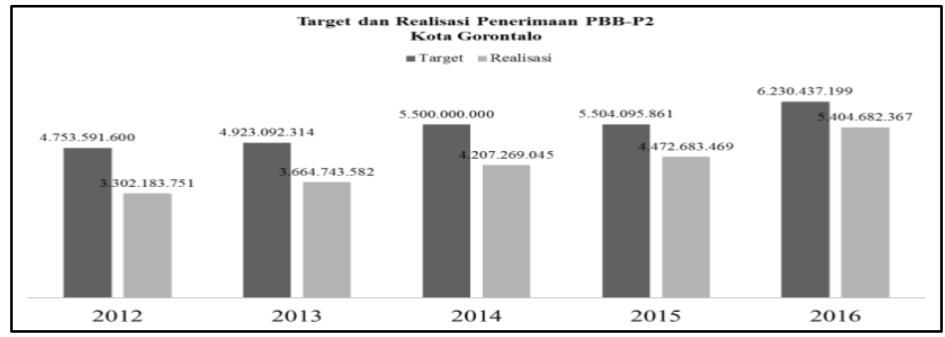

Sumber : Hasil Data Olahan (2017)

Kondisi yang terjadi adalah peningkatan target dan realisasi penerimaan PBB-P2 di Kota Gorontalo tidak dukung dengan meningkatnya kontribusi PBB-P2 terhadap penerimaan asli daerah pada Pemerintah Kota Gorontalo. Kontribusi penerimaan PBB-P2 terhadap PAD pada tahun 2012 adalah sebesar 3,91\% dan tahun 2013 turun menjadi sebesar 3,77\%. Pada tahun 2014 kontribusi penerimaan PBB-P2 terhadap PAD menurun menjadi sebesar 3,37\% dan tahun 2015 turun menjadi 3,15\%. Kontribusi PBB-P2 terhadap PAD pada tahun 2016 turun kembali menjadi sebesar 3,14\%. Dapat disimpulkan bahwa kontribusi PBB-P2 terhadap penerimaan PAD pada Pemerintah Kota Gorontalo mengalami penurunan. Berikut gambar 2 yang menunjukkan grafik kontribusi penerimaan PBB-P2 terhadap PAD pada Pemerintah Kota Gorontalo:

Gambar 2: Grafik Kontribusi Penerimaan PBB-P2 terhadap PAD Kota Gorontalo

Tahun 2012-2016

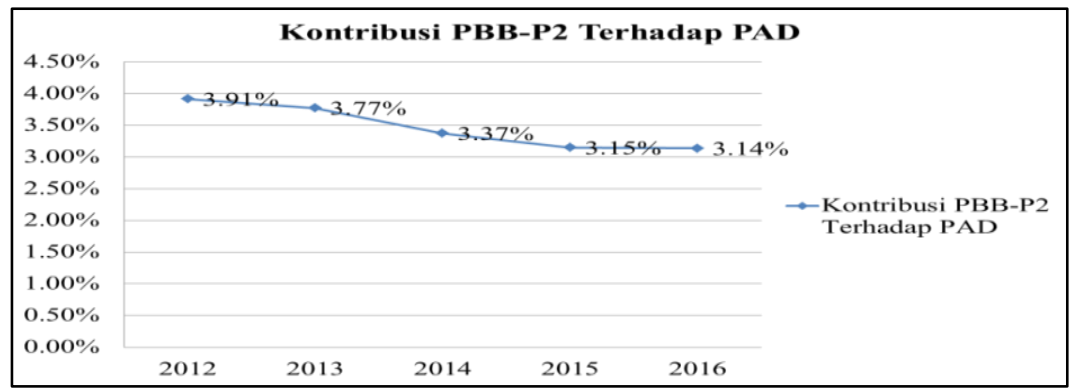

Sumber : Hasil Data Olahan (2017)

Kementerian Keuangan Republik Indonesia (2014:95) menyatakan bahwa hal-hal yang ditenggarai berpengaruh besar terhadap penerimaan PBB-P2 di daerah adalah: (a) Kesadaran masyarakat yang masih rendah dalam membayar pajak; (b) Masyarakat belum memahami fungsi 
pajak; (c) Kekeliruan dalam dokumen penetapan; (d) Tarif yang terlalu besar; (e) Belum tegasnya penerapan sanksi hukum terhadap pajak daerah; dan (f) Kurangnya sarana dan prasarana. Direktorat Jenderal Perimbangan Keuangan Kementerian Keuangan RI menyatakan bahwa PBB-P2 sebagai Pajak Daerah diharapkan dapat meningkatkan pendapatan daerah dalam rangka memperbaiki kualitas pelayanan kepada masyarakat (2013:62). Hasil penelitian yang dilakukan Rahayu dan Halim (2016) menyimpulkan bahwa kendala yang dihadapi dalam pengelolaan PBB-P2 di DPDPK Kota Yogyakarta adalah tidak ada SOP pengelolaan PBB P2,penilaian untuk reklasifikasi NJOP, peraturan walikota untuk NJOP dan pemutakhiran basis data. Penelitian yang dilakukan oleh Fajri (2016) menyimpulkan bahwa hambatan yang dihadapi oleh DPPKAD Kabupaten Sukoharjo dalam penerimaan PBB-P2 berasal dari faktor internal meliputi : bidang kebijakan, sistem administrasi, konsistensi, dan sumber daya manusia. dan faktor eksternal yang meliputi: sikap dan kesadaran wajib pajak, dan persesuaian data dengan realitas lapangan.

Tujuan penelitian ini adalah : (1) Untuk menganalisis Penerimaan Pajak Bumi dan Bangunan Perdesaan dan Perkotaan (PBB-P2) terhadap kontribusi Pendapatan Asli Daerah di Kota Gorontalo; (2) Untuk menganalisis faktor-faktor penghambat penerimaan Pajak Bumi dan Bangunan Perdesaan dan Perkotaan (PBB-P2) terhadap kontribusi Pendapatan Asli Daerah di Kota Gorontalo; (3) Untuk menganalisis faktor-faktor pendukung penerimaan Pajak Bumi dan Bangunan Perdesaan dan Perkotaan (PBB-P2) terhadap kontribusi Pendapatan Asli Daerah di Kota Gorontalo.

\section{Model Analisis}

Penerimaan Pajak Bumi dan Bangunan Perdesaan dan Perkotaan (PBB-P2) diharapkan dapat berkontribusi terhadap peningkatan Pendapatan Asli Daerah (PAD) di Kota Gorontalo. Agar penelitian ini lebih terarah sesuai dengan rumusan masalah dan tujuan penelitian yang ingin dicapai, maka penulis menyusun model analisis sebagaimana pada Gambar 3 berikut:

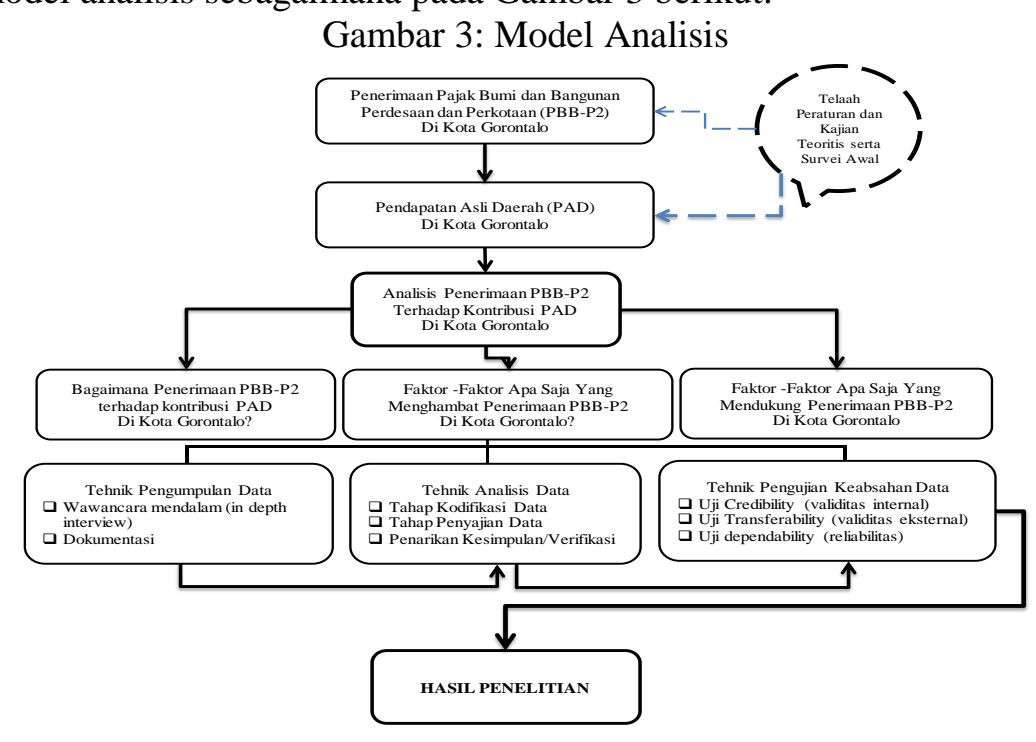

\section{Metode Penelitian}

Penelitian ini adalah jenis penelitian kualitatif dengan pendekatan studi kasus. Creswell (2014:32) menyatakan bahwa penelitian kualitatif merupakan metode-metode untuk mengekplorasi dan memahami makna yang oleh sejumlah individu atau sekelompok orang dianggap berasal dari masalah sosial atau kemanusiaan. Menurut Sugiyono (2015:1) metode penelitian kualitatif adalah metode penelitian yang digunakan untuk meneliti pada kondisi obyek yang alamiah, (sebagai lawannya adalah eksprimen) dimana peneliti adalah sebagai instrumen kunci, tehnik pengumpulan data adalah triangulasi (gabungan), analisis data bersifat induktif, dan hasil penelitian kualitatif lebih menekankan makna dari pada generalisasi.

Lokasi penelitian ini adalah pada Organisasi Perangkat Daerah (OPD) Kota Gorontalo, yaitu Badan Keuangan, Kecamatan dan Kelurahan yang mengelola penerimaan PBB-P2 sebagai pajak daerah. Waktu penelitian dilaksanakan pada bulan Juni sampai dengan bulan Agustus tahun 2017 atau selama 3 (tiga) bulan.

Instrumen penelitian adalah alat-alat yang diperlukan atau yang dipergunakan untuk mengumpulkan data (Afrizal, 2016:134). Dalam penelitian ini yang menjadi instrument penelitian 
utama adalah peneliti sendiri sebagaimana menurut Sugiyono (2014:305) bahwa dalam penelitian kualitatif, yang menjadi instrumen atau alat penelitian adalah peneliti itu sendiri.

Untuk mengumpulkan data dari sumber informasi (informan), maka dalam penelitian ini akan menggunakan 2 ( dua) macam instrument bantuan, yaitu: (1) Panduan atau pedoman wawancara; (2) Alat rekaman.

Penentuan informan dalam penelitian ini dilakukan dengan tehnik purposive sampling yaitu, menetapkan kriteria tertentu yang harus dipenuhi oleh informan yang akan dijadikan sumber informasi. Kriteria informan dalam penelitian ini adalah Aparatur Sipil Negara (ASN) yang melaksanakan tugas dan menyelenggarakan fungsi pengelolaan PBB-P2 sebagai pendapatan asli daerah di Kota Gorontalo.

Menurut Bungin (2013:123) data adalah bahan keterangan tentang sesuatu objek penelitian. Jenis data yang digunakan dalam penelitian ini adalah data kualitatif dan data kuantitatif. Riduwan (2010:106) menyatakan bahwa data kualitatif yaitu data yang data yang berhubungan dengan kategorisasi, karakteristik berwujud pertanyaan atau berupa kata-kata dan data kuantitatif yaitu data yang berwujud angka-angka. Sumber data dalam penelitian ini adalah sumber data primer dan sekunder.

\section{Tehnik Pengumpulan Data}

Tehnik pengumpulan data pada penelitian ini dilakukan dengan cara sebagai berikut : (1) Wawancara mendalam (in depth interview).Menurut Moleong (2014:186) wawancara adalah percakapan dengan maksud tertentu. Noor (2014:139) menyatakan bahwa wawancara mendalam (indepth interview) adalah proses memperoleh keterangan untuk tujuan penelitian dan cara tanya jawab sambil bertatap muka antara pewawancara dengan informan atau orang yang diwawancarai, dengan atau tanpa pedoman wawancara, dimana pewawancara dan informan terlibat dalam kehidupan sosial yang relatif lama; (2) Dokumentasi. Dokumen digunakan untuk mendukung hasil observasi dan wawacara. Dokumen merupakan catatan peristiwa yang yang sudah berlalu (Sugiyono, 2015:82). Bungin (2014:155) membagi jenis dokumen menjadi 2 (dua), yaitu dokumen pribadi dan dokumen resmi. Penelitian menggunakan dokumen resmi berupa dokumen internal dan dokumen eksternal.

Miles dan Huberman (Afrizal, 2016:178) membagi analisis data dalam penelitian kualitatif kedalam tiga tahap, yaitu kodifikasi data, penyajian data, dan penarikan kesimpulan/verifikasi. Berikut tahap-tahap tehnik analisis data yang akan dilakukan dalam penelitian ini : (1) Tahap kodifikasi data, dilakukan dengan cara menulis kembali catatan-catatan lapangan yang dibuat pada saat wawancara mendalam dilakukan, yang diawali dengan membuat transkrip hasil rekaman wawancara. Setelah itu memberikan tanda-tanda (kodifikasi) dengan memilah informasi yang penting dan tidak penting berdasarkan catatan dan transkip rekaman wawancara.; (2) Tahap penyajian data, Penelitian ini akan menyajikan temuan hasil penelitian dalam bentuk matrik dan diagram; (3) Tahap penarikan kesimpulan atau verifikasi adalah suatu tahap lanjutan dimana pada tahap ini akan menarik kesimpulan dari temuan data, yaitu interpretasi atas temuan dari suatu wawancara atau sebuah dokumen. Setelah kesimpulan diambil dilakukan pengecekan atas kesahihan interpretasi dengan mengecek ulang koding dan penyajian data untuk memastikan tidak ada kesalahan yang telah dilakukan.

Pada tahap analisis data, peneliti menggunakan software program NVivo untuk membantu dalam proses kodifikasi data, penyajian data, dan penarikan kesimpulan/verifikasi.

Menurut Sugiyono (2014:361) uji keabsahan data dalam penelitian kualitatif meliputi uji credibility (validitas internal), transferability (validitas eksternal), dependability (reliabilitas) dan confirmability (objektivitas). Tehnik pengujian keabsahan data dalam penelitian ini dilakukan dengan cara sebagai berikut : (1) Uji Credibility (Validitas Internal); (2) Pengujian Transferability; (3) Uji Dependability.

\section{Hasil Penelitian Dan Pembahasan \\ Analisis Data}

Berdasarkan hasil penelitian dari wawancara dengan informan, hasil analisis data untuk rumusan masalah pertama, bagaimana penerimaan PBB-P2 terhadap kontribusi PAD di Kota Gorontalo? ditemukan 2 (dua) tema penelitian, yaitu : (1) Penetapan target penerimaan;dan (2) Potensi Penerimaan. Untuk rumusan masalah kedua, faktor-faktor yang menghambat penerimaan PBB-P2 terhadap kontribusi PAD di Kota Gorontalo?, ditemukan 3 (tiga) tema penelitian, yaitu : (1) Kesadaran wajib pajak; (2) Kekeliruan dalam dokumen penetapan; dan (3) Sumber daya manusia (penilai). Pada rumusan masalah ketiga, faktor-faktor yang mendukung penerimaan PBB-P2 terhadap kontribusi PAD di Kota Gorontalo?, ditemukan 3 (tiga) tema penelitian, yaitu : (1) Kepemimpinan; (2) Sumber daya manusia (kolektor); dan (3) Kompensasi. 


\section{Pembahasan}

\section{Penentuan Target Penerimaan PBB-P2}

Menurut Direktorat Jenderal Pajak Kementerian Keuangan RI (2014:92) metode penentuan target penerimaan pajak terdiri atas : (a) Metode Top Down; (b) Metode Bottom Up. Berdasarkan hasil penelitian penentuan target penerimaan PBB-P2 di Kota Gorontalo dilakukan dengan top down dengan menentukan target daerah terlebih dahulu kemudian dibreak down menjadi target penerimaan per kecamatan. Untuk menganalisa penerimaanPBB-P2 di Kota Gorontalo berdasarkan target penerimaan dilakukan dengan menghitung rasio pengumpulan (collection ratio), yaitu rasio yang digunakan untuk mengukur persentase realisasi penerimaan pajak daerah dari target penerimaan pajak daerah (Kementerian Keuangan RI, 2013:89).

Rumus rasio pengumpulan (collection ratio) pajak daerah:

$$
\text { RPPXi }=\frac{\text { Realisasi Xi }}{\text { Target Xi }} \times 100 \%
$$

$$
\begin{array}{ll}
\mathrm{RPP} & =\text { Rasio pengumpulan pajak } \\
\mathrm{Xi} & =\text { Jenis Pajak Daerah tahun berkenaan }
\end{array}
$$

Presentasi realisasi penerimaan PBB-P2 Kota Gorontalo berdasarkan rasio pengumpulan pajak daerah 2012-2016 dapat dilihat pada tabel 1 berikut:

Tabel 1: Rasio Pengumpulan Kota Gorontalo

PBB-P2 Tahun 2012-2016

\begin{tabular}{|c|c|c|c|c|}
\hline No. & Tahun & Target & Realisasi & $\begin{array}{c}\text { Rasio } \\
\text { Pengumpulan }\end{array}$ \\
\hline 1 & 2 & 3 & 4 & 5 \\
\hline 1. & 2012 & $4,753,591,600.00$ & $3,302,183,751.00$ & $69.47 \%$ \\
\hline 2. & 2013 & $4,923,092,314.00$ & $3,664,743,582.00$ & $74.44 \%$ \\
\hline 3. & 2014 & $5,500,000,000.00$ & $4,207,269,045.00$ & $76.50 \%$ \\
\hline 4. & 2015 & $5,504,095,861.00$ & $4,472,683,469.00$ & $81.26 \%$ \\
\hline 5. & 2016 & $6,230,437,199.00$ & $5,404,682,367.00$ & $86.75 \%$ \\
\hline
\end{tabular}

Sumber Data: Hasil Olahan (2017)

Penetapan target penerimaan dilakukan oleh Badan Keuangan Kota Gorontalo dengan mempertimbangkan realisasi penerimaan tahun sebelumnya dan melakukan penyesuaian data atas objek serta subjek pajak. Badan Keuangan Kota Gorontalo merupakan suatu lembaga Pemerintah Kota Gorontalo yang dapat dipercaya untuk bertindak dengan sebaik-baiknya untuk menetapkan target penerimaan PBB-P2 di Kota Gorontalo dan meningkatkan pendapatan daerah. Manossoh (2016:17) menyatakan bahwa teori stewardship melihat manajemen sebagai dapat dipercaya untuk bertindak dengan sebaik-baiknya bagi kepentingan publik maupun stakeholder berdasarkan asumsi bahwa manusia pada hakekatnya dapat dipercaya, mampu bertindak dengan penuh tanggung jawab, memiliki integritas dan kejujuran terhadap pihak lain.

\section{Potensi Penerimaan PBB-P2 Di Kota Gorontalo}

Kementerian Keuangan RI (2014:93) menyatakan bahwa klasifikasi potensi penerimaan pajak dapat digolongkan menjadi : (a) Penerimaan Prima; (b) Penerimaan Potensial; (c) Berkembang; (d) Terbelakang. Untuk menentukan potensi penerimaan pajak daerah ke dalam klasifikasi tersebut diperlukan 2 indikator pokok, yaitu: (a) Rasio Proporsi; dan (b) Rasio Tambahan. Berikut Tabel 2 yang menunjukkan rasio proporsi penerimaan PBB-P2 di Kota Gorontalo :

Tabel 2: Rasio Proporsi Penerimaan PBB-P2 Kota Gorontalo

Tahun 2012-2016

\begin{tabular}{|c|c|c|c|c|c|c|}
\hline No. & Tahun & Realisasi PBB-P2 & $\begin{array}{c}\text { Realisasi Pajak } \\
\text { Daerah }\end{array}$ & $\begin{array}{c}\text { Jenis } \\
\text { Pajak } \\
\text { Daerah }\end{array}$ & $\begin{array}{c}\text { Rata-Rata Pajak } \\
\text { Daerah }\end{array}$ & $\begin{array}{c}\text { Rasio } \\
\text { Proporsi }\end{array}$ \\
\hline 1 & 2 & 3 & 4 & 5 & 6 & 7 \\
\hline 1. & 2012 & $3,302,183,751.00$ & $24,180,000,000.00$ & 9 & $2,686,666,666.67$ & 1.23 \\
\hline 2. & 2013 & $3,664,743,582.00$ & $29,940,000,000.00$ & 9 & $3,326,666,666.67$ & 1.10 \\
\hline 3. & 2014 & $4,207,269,045.00$ & $30,670,000,000.00$ & 9 & $3,407,777,777.78$ & 1.23 \\
\hline 4. & 2015 & $4,472,683,469.00$ & $34,590,000,000.00$ & 9 & $3,843,333,333.33$ & 1.16 \\
\hline 5. & 2016 & $5,404,682,367.00$ & $45,680,000,000.00$ & 9 & $5,075,555,555.56$ & 1.06 \\
\hline
\end{tabular}

Sumber: Data Hasil Olahan (2017) 
Berikut Tabel 3 yang menunjukkan rasio tambahan/pertumbuhan penerimaan PBB-P2 di Kota Gorontalo:

Tabel 3: Rasio Pertumbuhan PBB-P2 Kota Gorontalo

Tahun 2013-2016

\begin{tabular}{|c|c|c|c|c|}
\hline No. & Tahun & $\begin{array}{c}\text { Pertumbuhan } \\
\text { PBB-P2 }\end{array}$ & $\begin{array}{c}\text { Pertumbuhan } \\
\text { Pajak Daerah }\end{array}$ & $\begin{array}{c}\text { Rasio } \\
\text { Pertumbuhan/ } \\
\text { Tambahan }\end{array}$ \\
\hline 1 & 2 & 3 & 4 & 5 \\
\hline 1. & 2012 & - & - & 0.46 \\
\hline 2. & 2013 & 0.11 & 0.24 & 6.07 \\
\hline 3. & 2014 & 0.15 & 0.02 & 0.49 \\
\hline 4. & 2015 & 0.06 & 0.13 & 0.65 \\
\hline 5. & 2016 & 0.21 & 0.32 & \\
\hline
\end{tabular}

Sumber: Data Hasil Olahan (2017)

Untuk mengetahui klasifikasi potensi penerimaan PBB-P2 di Kota Gorontalo dilakukan dengan menggunakan rumusan klasifikasi potensi pada gambar 4 berikut:

Gambar 4

Rumusan klasifikasi Potensi

\begin{tabular}{|c|c|c|}
\hline & \multicolumn{2}{|c|}{ Rasio Proporsi } \\
\hline Rasio Pertumbuhan & $\frac{\text { XI }}{\text { Rata-rata X }}>1$ & $\frac{\text { XI }}{\text { Rata-rata X }}<1$ \\
\hline rPXI & Prima & Berkembang \\
\hline rPtotal & Potensial & Terbelakang \\
\hline rPXI & & \\
\hline
\end{tabular}

Sumber : Kementerian Keuangan RI (2013:90)

Keterangan

rPXI : Pertumbuhan penerimaan Jenis Pajak Daerah

rPXtotal : Pertumbuhan total penerimaan seluruh Pajak Daerah

XI : Rata-rata penerimaan seluruh Pajak Daerah

Berikut tabel 4 yang menunjukkan rasio proporsi dan rasio pertumbuhan pajak daerah serta klasifikasi potensi penerimaan PBB-P2 sebagai Pajak Daerah di Kota Gorontalo:

Tabel 4

Rasio Proporsi dan Rasio Pertumbuhan PBB-P2

Kota Gorontalo Tahun 2013- 2016

\begin{tabular}{|c|c|c|c|c|}
\hline No. & Tahun & Rasio Proporsi & $\begin{array}{c}\text { Rasio } \\
\text { Pertumbuhan }\end{array}$ & Klasifikasi \\
\hline 1 & 2 & 3 & 4 & 5 \\
\hline 1. & 2012 & 1.23 & - & - \\
\hline 2. & 2013 & 1.10 & 0.46 & Potensial \\
\hline 3. & 2014 & 1.23 & 6.07 & Prima \\
\hline 4. & 2015 & 1.16 & 0.49 & Potensial \\
\hline 5. & 2016 & 1.06 & 0.65 & Potensial \\
\hline
\end{tabular}

Sumber : Data Hasil Olahan (2017)

Sesuai dengan Tabel 4, dapat disimpulkan bahwa klasifikasi penerimaan PBB-P2 di Kota Gorontalo berdasarkan analisis rasio proporsi dan rasio pertumbuhan adalah potensial

\section{Faktor-Faktor Penghambat Penerimaan PBB-P2 Di Kota Gorontalo \\ Kesadaran Wajib Pajak}

Kementerian Keuangan RI (2014:95) menyatakan bahwa hal-hal ditenggarai berpengaruh besar terhadap penerimaan PBB-P2 di daerah salah satunya adalah kesadaran masyarakat yang masih rendah dalam membayar pajak. Harahap (2004:43) menyatakan bahwa Kesadaran wajib pajak adalah sikap mengerti wajib pajak badan atau perorangan untuk memahami arti, fungsi dan tujuan pembayaran pajak. Sementara menurut Suandy (2011:128) menyatakan bahwa kesadaran wajib pajak artinya wajib pajak mau dengan sendirinya melakukan kewajiban perpajakannya seperti mendaftarkan diri, menghitung, membayar dan melaporkan jumlah pajak terutangnya.Pajak adalah kewajiban yang harus 
dilaksanakan oleh masyarakat kepada pemerintah untuk membiayai penyelenggaraan pemerintahan. Kewajiban tersebut menuntut kesadaran masyarakat sebagai wajib pajak untuk memenuhi kewajibannya.

\section{Kekeliruan Dalam Dokumen Penetapan}

Inti persoalan perpajakan adalah siapa yang harus membayar pajak dan berapa besarnya pajak yang terutang. Masalah siapa yang harus membayar pajak adalah persoalan subjek pajak, yang terdiri dari orang pribadi atau badan, sedang berapa besar pajak terhutang, menyangkut masalah objek pajak, tarif pajak, dan dasar pengenaan pajak. Apabila subjek pajak ada objek pajaknya, maka dia disebut wajib pajak (taxpayer), dan apabila tarif dikalikan dengan dasar pengenaan pajak, maka akan diperoleh pajak terhutang (Diana Sari, 2013:93). Kementerian Keuangan RI (2014:95) menyatakan bahwa halhal ditenggarai berpengaruh besar terhadap penerimaan PBB-P2di daerah salah satunya adalah terjadinya kekeliruan atau kesalahan dalam penetapan besarnya pajak. Dalam pemungutan PBB-P2 di Kota Gorontalo, basis data yang yang digunakan adalah basis data yang diserahkan oleh Kementerian Keuangan Republik Indonesia. Penyerahan basis data PBB-P2 dilakukan oleh Direktorat Jenderal Pajak sebagaimana tugas dan tanggung jawab Kementerian Keuangan Republik Indonesia dalam Peraturan Bersama Menteri Keuangan dan Menteri dalam Negeri Nomor 15/PMK.07/2014 Nomor 10 Tahun 2014 tentang Tahapan Persiapan Pengalihan Pajak bumi dan Bangunan Perdesaan Dan Perkotaan Sebagai Pajak Daerah.

\section{Sumber Daya Manusia (SDM)}

Dalam rangka pengelolaan PBB-P2 menurut Kementerian Keuangan RI (2014:14),salah satu fungsi SDM yang dibutuhkan dalam pengelolaan PBB-P2 yaitu: (Fungsi pendataan dan penilaian: Spesifikasi yang dibutuhkan antara lain pegawai harus dapat melakukan pendataan dan penatausahaan hasil pendataan (pembentukan dan/atau pemeliharaan basis data) objek dan subjek pajak, membuat laporan analisis indikasi nilai pasar properti untuk pembentukan bank data nilai pasar properti serta laporan analisis upah pekerja dan harga bahan bangunan untuk penyusunan Daftar Biaya Komponen Bangunan (DBKB). Menteri Keuangan RI mendefinisikan penilai adalah seseorang yang dengan keahliannya menjalankan kegiatan penilaian. Definisi penilai menurut Masyarakat Profesi Penilai Indonesia (MAPPI) adalah orang perseorangan yang melakukan kegiatan penilaian sesuai dengan keahlian dan profesionalisme yang dimiliki dan menjadi anggota assosiasi profesi penilai yang diakui oleh pemerintah serta mengacu kepada Standar Penilaian Indonesia(SPI), Kode Etik Penilai Indonesia (KEPI) dan standar keahlian lainnya yang terkait dengan kegiatan penilaian (Supriyanto, 2011:5). Salah satu konsekuensi pengalihan PBB-P2 menjadi pajak daerah adalah keharusan bagi pemerintah daerah untuk mampu melakukan kegiatan pendataan dan penilaian. Dalam melakukan kegiatan penilaian Objek PBB-P2, Pemerintah Kota Gorontalo terkendala dengan tidak tersedianya SDM yaitu aparatur yang memiliki keahlian dalam melakukan penilaian.

\section{Faktor-Faktor Pendukung Penerimaan Penerimaan PBB-P2 Di Kota Gorontalo Kepemimpinan}

Menurut Suwatno dan Priansa (2011:166) pemimpin adalah pribadi yang memiliki superioritas tertentu, sehingga dia memiliki kewibawaan dan kekuasaan untuk menggerakkan orang lain melakukan usaha bersama guna mencapai tujuan tertentu. Thoha (2015:1) menyatakan bahwa suatu organisasi akan berhasil atau bahkan gagal sebagian besar ditentukan oleh kepemimpinan. Kepemimpinan lurah dan camat menjadi faktor yang mendukung penerimaan PBB-P2 di Kota Gorontalo.

\section{Sumber Daya Manusia}

Sumber daya manusia adalah faktor utama dalam sebuah organisasi apapun bentuknya. Menurut Nawawi (2006:305) sumber daya manusia adalah faktor sentral di lingkungan organisasi provit (perusahaan dan industry), non provit (instansi pemerintah), dan voluntir (organisasi/perkumpulan berdasarkan kemanusiaan dan pengabdian). Oleh karenanya sumber daya manusia pada lingkungan organisasi harus dikelola dengan efektif dan efisien untuk mencapai tujuan organisasi. Salah satu upaya yang dapat dilakukan dalam pengelolaan atau manajeman sumber daya manusia untuk mencapai tujuan organisasi adalah pemberdayaan manusia sebagai sumber daya secara maksimal. Pelaksanaan pemungutan PBB-P2 tidak lepas dari peran petugas pemungut/penagih yang lebih dikenal dengan kolektor di Kota Gorontalo. Kolektor PBB-P2 di Kota Gorontalo adalah aparatur pemerintah dikelurahan yang sebagian besar merupakan mantan kepala lingkungan yang berdomisili pada wilayah penagihannya. Hal ini menjadi faktor yang mendukung penerimaan PBB-P2 di Kota Gorontalo.

\section{Kompensasi}


Menurut Edison, Anwar dan Komariyah (2016:157) insentif adalah bentuk kompensasi diluar upah yang diberikan kepada karyawan atas usaha tambahannya dalam membantu perusahaan. Sedarmayanti (2011:237) menyatakan bahwa bentuk insentif, yaitu: (1) piecework; (2) Production bonuses; (3) Commissions; (4) Maturity curves; (5) Merit raises; (6) Pay-for-knowledge/pay-for-skill; (7) Non-monetery incentives; (8) Executive insentives; (9) Internatinal incentives. Prinsip penting dalam sistem manajemen kompensasi adalah prestasi yang tinggi harus diberi penghargaan (reward) yang layak, sedangkan kinerja yang buruk diberi hukuman (punishment) yang adil dan manusiawi. Manajemen kompensasi yang baik adalah manajemen kompensasi yang berorientasi pada pemberian penghargaan, bukan berorientasi pada hukuman (Mahmudi, 2015:175).

Sedarmayanti (2011:240) manfaat pemberian penghargaan adalah menarik, memotivasi, mengembangkan, memuaskan dan mempertahankan pekerja agar tidak meninggalkan organisasi. Menurut Mahmudi (2015:183) komponen reward selain gaji adalah kesejahteraan (benefit). Insentif yang diberikan pemerintah Kota Gorontalo adalah insentif yang diberikan berdasarkan ketentuan Peraturan Pemerintah Nomor 69 Tahun 2010 tentang Tata Cara Pemberian dan Pemanfaatan Insentif Pemungutan Pajak Daerah dan Retribusi Daerah. Sementara Reward yang diberikan pemerintah Kota Gorontalo adalah reward dalam bentuk liburan dan hadiah dalam bentuk barang elektronik. Pemberian insentif dan reward ini yang mendukung meningkatnya penerimaan PBB-P2 di Kota Gorontalo.

\section{Daftar Pustaka}

Abdul Asri Harahap, 2004, Paradigma Baru Perpajakan Indonesia. BPFE Yogyakarta

Afrizal, 2016, Metode Penelitian Kualitatif Sebuah Upaya Mendukung Penggunaan Penelitian Kualitatif Dalam Berbagai Displin Ilmu, Cetakan ke-3, PT. RajaGrafindo Persada, Jakarta

Ahmad Frendi Habibi, 2015, Implementasi Kebijakan Pemberian Reward Untuk Meningkatkan

Burhan Bungin, 2015, Analisis Data Penelitian Kualitatif Pemahaman Filosofis dan Metodologis ke Arah Penguasaan Aplikasi Cetakan ke-9, PT. RajaGrafindo Persada, Jakarta

Eko Raharjo, 2007, Teori Agensi Dan Teori Stewardship Dalam Perspektif Akuntansi, Jurnal Fokus Ekonomi, Vol.2 No. 1 Juni $2007: 37-46$

Emron Edison, Yohny Anwar \& Imas Komariyah, 2016, Manajemen Sumber Daya Manusia Cetakan Kesatu, CV. Alfabeta, Bandung

Erly Suandy, 2011, Hukum Pajak . Edisi 5, Salemba Empat, Jakarta

Hadari Nawawi, 2006, Kepemimpinan Mengefektifkan Organisasi Cetakan Kedua, Gadjah Mada University Press, Yogyakarta

Hendrik Manossoh, 2016, Good Corporate Governance Untuk Meningkatkan Kualitas Laporan Keuangan, PT. Norlive Kharisma Indonesia, Bandung

Heru Supriyanto, 2010, Cara Menghitung PBB, BPHTB, dan Bea Materai, PT. Indeks, Jakarta

Heru Supriyanto, 2011, Penilaian Propert Tujuan PBB, PT. Indeks, Jakarta

Juliansyah Noor, 2014, Metode Penelitian: Skripsi, Tesis, Disertasi, dan Karya Ilmiah Edisi Pertama Cetakan ke-4, Kencana Prenadamedia Group, Jakarta

John. W. Creswell, 2014, Research design : qualitative, quantitative, and mixed methods approaches / John W. Creswell. - 4th ed., SAGE Publications, Inc

Kementerian Keuangan, 2013, Handbook Modul Pendapatan Daerah, Direktorat Jenderal Perimbangan Keuangan, Jakarta

Kementerian Keuangan, 2014, Pedoman Umum Pengelolaan PBB-P2, Direktorat Jenderal Perimbangan Keuangan, Jakarta

Lexy J. Moleong, 2014, Metodologi Penelitian Kualitatif, PT. Remaja Rosdakarya, Bandung

Mahmudi, 2015, Manajemen Kinerja Sektor Publik Edisi Ketiga Cetakan Pertama, Unit Penerbit Dan Percetakan STIM YKPN, Yogyakarta

Peraturan Pemerintah Nomor 69 Tahun 2010 tentang Tata Cara Pemberian Insentif Pemungutan Pajak Daerah dan Retribusi Daerah

Peraturan Daerah Kota Gorontalo Nomor 9 Tahun 2011 tentang Pajak Bumi dan Bangunan Perdesaan dan Perkotaan

Peraturan Daerah Nomor 8 Tahun 2012 tentang Perubahan Atas Peraturan Daerah Nomor 9 Tahun 2011 tentang Pajak Bumi dan Bangunan Perdesaan dan Perkotaan

Hastanti Agustin Rahayu dan Abdul Halim, 2016, Evaluasi Pengelolaan Pajak Bumi dan Bangunan Perdesaan dan Perkotaan: Studi Pada Pemerintah Kota Yogyakarta, Jurnal Riset Manajemen, $3(1)$ 
Hafidh Al Fajri 2016, Kinerja DPPKD Dalam Meningkatkan Penerimaan Sektor Pajak Bumi dan Bangunan Di Kabupaten Sukoharjo Provinsi Jawa Tengah, JI@ P, 3(1).

Riduwan, 2014, Metode dan Tehnik Menyusun Tesis Cetakan Ke-10, Alfabeta, Bandung

Robert K. Yin, 2015, Studi Kasus Desain dan Metode Cetakan ke-14,PT. RajaGrafindo Persada, Jakarta

Sedarmayanti, 2011, Membangun dan Mengembangkan Kepemimpinan Serta Meningkatkan Kinerja Untuk Meraih Keberhasilan, PT. Refika Aditama, Bandung

Sedarmayanti, 2010, Reformasi Administrasi Publik, Reformasi Birokrasi, Dan Kepemimpinan Masa Depan (Mewujudkan Pelayanan Prima dan Kepemerintahan Yang Baik), Cetakan Kedua, PT. Refika Aditama, Bandung

Sugiyono, 2015, Memahami Penelitian Kualitatif, CV. Alfabeta, Bandung

Suwatno dan Donni Juni Priansa, 2011, Manajemen SDM Dalam Organisasi Publik dan Bisnis Cetakan Kedua, Penerbit Alfabeta, Bandung

Undang-Undang 28 Tahun 2009 tentang Pajak Daerah dan Retribusi Daerah 